\section{Yield and Relationships among Head Traits in Cabbage as Influenced by Planting Date and Cultivar. I. Fresh Market}

\author{
Matthew D. Kleinhenz ${ }^{1}$ and Annette Wszelaki ${ }^{2}$ \\ Department of Horticulture and Crop Science, The Ohio State University, Ohio \\ Agricultural Research and Development Center (OARDC), 1680 Madison \\ Avenue, Wooster, OH 44691-4096 \\ Additional index words. Brassica oleracea, Capitata Group, crop quality, cole crops, head \\ dimensions
}

\begin{abstract}
Yield and relationships among head traits were recorded in order to better understand the effects of planting date and cultivar selection on crop quality characteristics and to help increase the efficiency of cultivar development, evaluation, and selection. A total of seven cultivars of fresh market-type cabbage (Brassica oleracea L., Capitata Group) were planted in May and June of 1999 and 2000 at the OARDC Vegetable Crops Research Branch in Fremont, Ohio. Total and marketable yield, head traits (e.g., size, weight, density), and core dimensions were recorded at harvest. Main effects of year ( $Y$ ), planting date $(\mathrm{PD})$, and cultivar $(\mathrm{C})$ and the $\mathrm{Y} \times \mathrm{C}$ interaction significantly affected seven to 10 of 10 head and core traits. However, the $\mathrm{PD} \times \mathrm{C}$ interaction was significant for head density, the ratio of head polar and equatorial diameter, and core base width. The $Y \times$ PD interaction was significant for six of 10 head and core traits. May planting tended to result in greater yield and larger, heavier heads with greater polar/equatorial diameter values relative to June planting. However, head density was unaffected by planting date. The number of head and core traits affected by planting date differed among cultivars. For example, six of $\mathbf{1 0}$ head and core traits were significantly affected by planting date in 'Cheers' and 'DPSX315' while one trait was affected by planting date in 'SuperElite Hybrid'. The weight of numerous, individual, market-ready, trimmed heads showed a strong (avg. $R^{2}$ value $\left.=0.92\right)$ quadratic relationship to average head diameter. These data suggest that large-scale germplasm evaluations may benefit by including multiple plantings, as head weight, volume, diameter, and shape were affected by planting date, possibly due to variation in temperature and rainfall patterns. The data also suggest that routine measurement of numerous head traits in the same evaluations may be unnecessary, as selected traits (e.g., diameter and weight, head volume, and core volume) were strongly related.
\end{abstract}

Studies in Florida, Puerto Rico, and the Netherlands have helped describe the influence of genetic and abiotic factors on yield and important traits of cabbage. Genotype, season, or planting date affected total and marketable yield, head weight, shape, and firmness, and core dimensions (de Moel and Everaarts, 1990; Fornaris-Rullan et al., 1989; Howe and Waters, 1994; Strandberg and White, 1979). de Moel and Everaarts (1990) found smaller, lighter

Received for publication 1 Oct. 2002. Accepted for publication 9 Mar. 2003. Manuscript number HCS03-10. Salaries and research support provided in part by State and Federal funds appropriated to the Ohio Agricultural Research and Developmen Center, The Ohio State Univ. Work also supported in part by grants from the Ohio Vegetable and Smal Fruit Research and Development Program. The many important contributions of Brenda Schult and staff of the OARDC Vegetable Crops Research Branch in Fremont, Ohio, are gratefully acknowledged. We thank Ted Radovich for his technical assistance and critical reading of the manuscript. Use of trade names does not imply endorsement of the products named nor criticism of similar ones not named.

${ }^{1}$ Assistant Professor; to whom reprint requests should be addressed. E-mail: kleinhenz.1@osu.edu

${ }^{2}$ Postdoctoral Research Associate. heads and lower marketable yield in June- and July-planted crops vs. May-planted crops but increases in core length with later planting in the Netherlands. Fornaris-Rullan et al. (1989) reported that head weight ranged from 0.63 to $1.73 \mathrm{~kg}$, diameter from 12.4 to $18.6 \mathrm{~cm}$, and length from 13.8 to $16.3 \mathrm{~cm}$ among $10 \mathrm{cab}$ bage cultivars planted in Puerto Rico. 'Bravo', 'Big Cropper', 'Market Prize', 'Rio Verde', and 'Titanic' had the best overall acceptability in taste panel tests in the same study. Howe and Waters (1994) reported significant year $x$ cultivar interactions in marketable yield, head weight and size, and other characteristics among 16 cabbage cultivars planted in two seasons in Florida. Differences among cultivars in major traits were also found in Louisiana, North Dakota, and Pennsylvania (Greenland et al., 2000; Orzolek et al., 2000; Sundstrom and Story, 1984). These reports notwithstanding, relatively less is known about the influence of abiotic factors on yield and important traits of cabbage compared to other major vegetable crops. Potential influences of climatic and genetic factors on relationships among key head traits are also not well understood, although head diameter, weight, and firmness are thought to increase, while moisture content may decrease during head formation and maturation (Isenberg et al., 1975; Strandberg, 1979). Therefore, additional study of cabbage growth is needed, especially under contrasting climatic conditions. The objectives of this study were to document planting date and cultivar effects on fresh market cabbage yield and head traits and to examine relationships among important head traits. Outcomes of this work are expected to include a greater understanding of planting date and cultivar effects on indicators of cabbage quality in Ohio and more efficient cultivar development, evaluation, and selection.

\section{Materials and Methods}

Plot establishment. Transplants of seven commercially important cultivars of fresh market cabbage ('Blue Dynasty', 'Bronco', 'Cheers', 'DPSX315', 'Emblem', 'Red Dynasty', 'SuperElite Hybrid') having two to four true leaves were planted in the field using a two-row Holland Finger transplanter (Holland Transplant Co., Holland, Mich.) on 11 May 1999, 18 June 1999, 12 May 2000, and 30 June 2000 at the Ohio Agricultural Research and Development Center (OARDC) Vegetable Crops Research Branch in Fremont. Two-row plots were arranged in a randomized complete-block design with four (2000) or five (1999) replications per year; each replication contained both planting dates and all cultivars within each planting date. Plots measured 4.6 $\mathrm{m}$ long with $76 \mathrm{~cm}$ between rows and $28 \mathrm{~cm}$ between transplants. Soil type in each year was a Kibbie Fine-Sandy Loam (fine-loamy, mixed, mesic Hapludalfs). Preplant fertilizer applications included $72 \mathrm{~kg} \cdot \mathrm{ha}^{-1} \mathrm{P}_{2} \mathrm{O}_{5}$ via 0-46-0 and $291 \mathrm{~kg} \cdot \mathrm{ha}^{-1} \mathrm{~K}_{2} \mathrm{O}$ via 0-0-60 in Sept.-Oct. 1998 and 1999 and $78 \mathrm{~kg} \cdot \mathrm{ha}^{-1} \mathrm{~N}$ via $45-0-0$ spread and incorporated $\approx 2$ weeks before planting in 1999 and 2000. Each transplant was provided with $\approx 150 \mathrm{~mL}$ of a dilute nutrient starter solution containing $\mathrm{N}$ and $\mathrm{P}$ at planting. Standard pest management strategies, based on scouting, thresholds, and application of labeled pesticides, were employed. Plots were irrigated (3.0 mm, 1 July; $12.7 \mathrm{~mm} 16$ July) in 1999 only.

Harvest and data collection. Plots were examined 2-3 times per week beginning $55 \mathrm{~d}$ after transplanting to assess harvest readiness. Specific harvest dates were selected based on estimated days to maturity from the seed source and visual examination of heads. At maturity (80-124 d after planting), all heads were collected from the center $3 \mathrm{~m}$ of both rows in each plot. Heads were scored as marketable or unmarketable (small, split, rotten, or containing evidence of damage due to physiological disorders, disease, or insect feeding) and weighed as a group. Five marketable heads were then selected at random from the harvested group for further evaluation. Five outer leaves were removed from each head before they were re-weighed individually using an electronic scale (FV-60KWP, A and D Co., Tokyo, or CW11-2EO, Ohaus, Pine Brook, N.J.). Heads were then cut in half longitudinally and the core length and base width and head polar and 

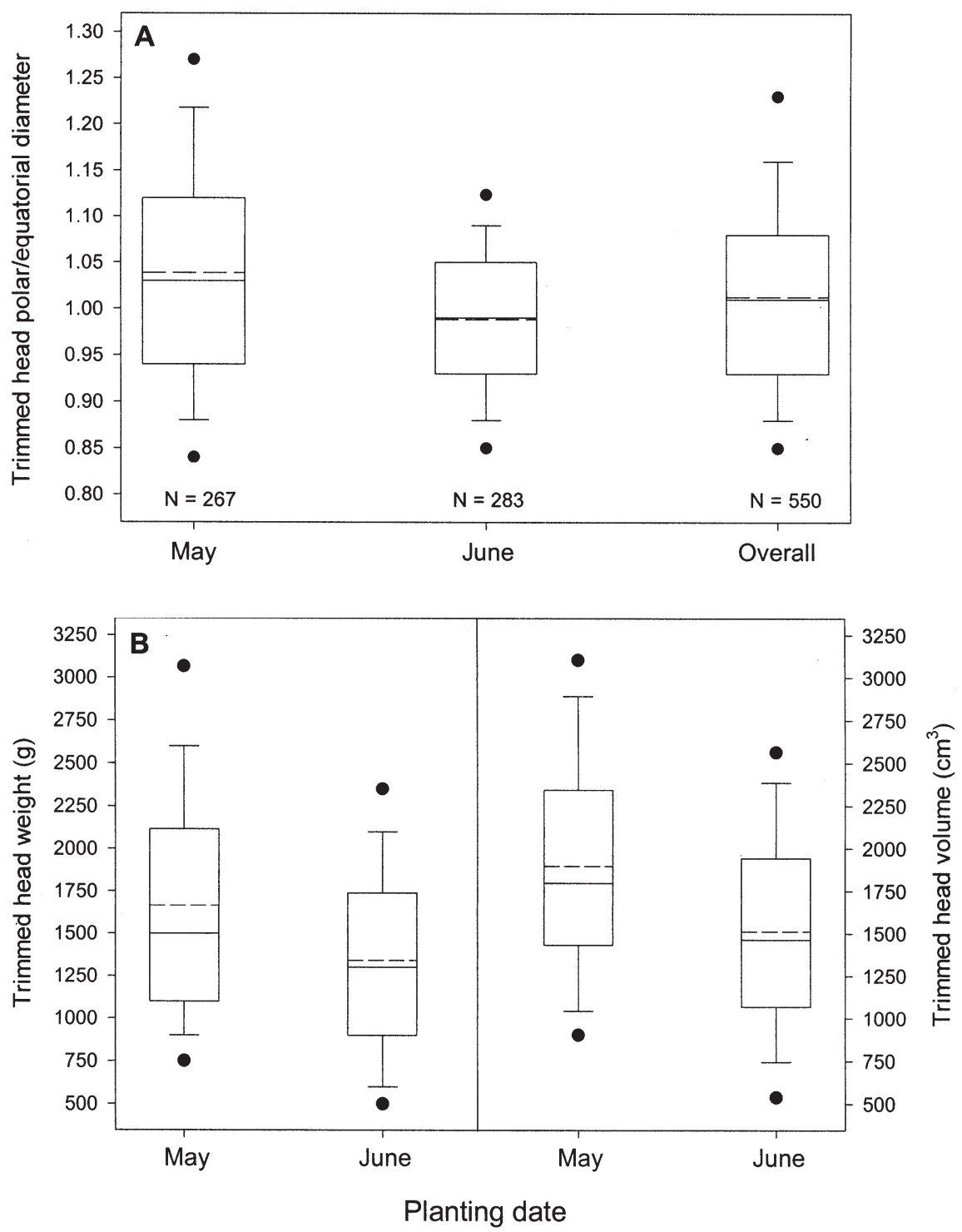

Fig. 1. Planting date effects on head traits of seven cultivars of fresh market cabbage planted in May and June of 1999 and 2000 at the OARDC Vegetable Crops Research Branch in Fremont, Ohio. (A) Distribution of trimmed head polar/equatorial diameter values. (B) Distribution of trimmed head (left) weight and (right) volume values. Shown in each panel are the 5th, 10th, 25th, 50th (median value), 75th, 90th, 95th percentiles (bottom-top) and mean (dashed line).

equatorial diameters were recorded. The ratio between head polar and equatorial diameter for the 550 heads examined rarely deviated significantly from 1 (Fig. 1A). Overall, $50 \%$ of the ratio values were in the range 0.93 to 1.08 with a mean value of 1.01 (Fig. 1A). Therefore, heads were treated as spheres in calculating head volume using average head diameter values and a standard geometric formula:

$$
\mathrm{V}=1.33 \cdot 3.1415927 \cdot \mathrm{r}^{3}
$$

where $r=$ average head radius. Head density $\left(\mathrm{g} \cdot \mathrm{cm}^{-3}\right)$ was then calculated using weight values taken at harvest and estimated head volume. The core was treated as a cone with core volume calculated as:

$$
\mathrm{V}=0.33 \cdot 3.1415927 \cdot \mathrm{r}^{2} \cdot \mathrm{h}
$$

with $\mathrm{r}=0.5 \cdot$ base width and $\mathrm{h}=$ core length.
The percent of the head volume contained in the core was calculated as the ratio of head to core volume. Thus, for each cultivar, direct measures of head weight, head polar and equatorial diameter, core length and base width were collected on 25 and 20 individual heads per planting date in 1999 and 2000, respectively (a total of at least 280 heads in each year).

Statistical analysis. Data were subjected to analysis of variance (ANOVA) to test main effects and interactions of year (Y), planting date (PD), and cultivar (C) using Statistical Analysis System version 7 for Windows (SAS Institute, Cary, N.C.). Fisher's least significant difference test $(\alpha=0.05)$ was used to compare treatment (year, planting date) means.

\section{Results}

Main effects and interactions on individual head and core traits. Main effects of year, planting date, and cultivar significantly $(P \leq 0.05)$ affected marketable yield and seven to 10 head and core traits (Table 1). In addition, interactions among main effects were significant $(P$ $\leq 0.05$ ) for marketable yield and three to nine head and core traits (Table 1). Changes in the direction of a response were rare as most significant interactions resulted from changes in magnitude (data not shown). Therefore, important trends are highlighted here. The $\mathrm{Y} \times$ $\mathrm{PD}$ and $\mathrm{PD} \times \mathrm{C}$ interactions were significant $(P \leq 0.05)$ for fewer head and core traits than the $\mathrm{Y} \times \mathrm{C}$ interaction (Table 1 ). Head density and the head polar: equatorial diameter were most frequently affected by interactions among year, planting date, and cultivar (Table 1). Head density was influenced by year and cultivar but not planting date (Table 1). When comparing seasonal mean values across all cultivars, planting in May tended to result in larger, heavier heads with greater polar/equatorial diameter (p/e) values compared to planting in June (Table 2). However, the average core volume accounted for $\approx 1 \%$ of the average calculated head volume, regardless of year or planting date. Mean core base width was greatest in May-planted crops (Table 2).

The effect of planting date on key head and core traits within individual cultivars is described in Table 3 . The data suggest that certain traits were more frequently influenced by planting date compared to other traits. The same data also suggest that the frequency with which head and core traits were influenced by planting date was partially genetically driven. For example, four traits (average head volume, polar diameter, p/e value, and core base width)

Table 1. Analysis of variance for the influence of year, planting date, and cultivar on head traits of seven cultivars of fresh market cabbage planted in May and

\begin{tabular}{|c|c|c|c|c|c|c|c|c|c|c|c|c|}
\hline \multirow[b]{3}{*}{ Source } & \multirow[b]{3}{*}{ df } & \multirow{3}{*}{$\begin{array}{c}\text { Marketable } \\
\text { yield }\end{array}$} & \multicolumn{7}{|c|}{ Trimmed head } & \multicolumn{3}{|c|}{ Core } \\
\hline & & & \multirow[b]{2}{*}{$\mathrm{Wt}$} & \multirow[b]{2}{*}{ Vol } & \multirow[b]{2}{*}{ Density } & \multicolumn{4}{|c|}{ Diameter } & \multirow[b]{2}{*}{ Length } & \multirow{2}{*}{$\begin{array}{r}\text { Base } \\
\text { width }\end{array}$} & \multirow{2}{*}{$\begin{array}{c}\% \text { Heac } \\
\text { vol }\end{array}$} \\
\hline & & & & & & Polar (P) & Equatorial (E) & Avg & $\mathrm{P} / \mathrm{E}$ & & & \\
\hline Year (Y) & 1 & $*$ & $* * *$ & $* * *$ & $* * *$ & $* * *$ & $* * *$ & $* * *$ & $* * *$ & $* * *$ & $*$ & NS \\
\hline Planting date (PD) & 1 & $* * *$ & $* * *$ & $* * *$ & NS & $* * *$ & $* * *$ & $* * *$ & $* * *$ & NS & $* * *$ & NS \\
\hline Cultivar (C) & 6 & $* * *$ & $* * *$ & $* * *$ & $* * *$ & $* * *$ & $* * *$ & $* * *$ & $* * *$ & $* * *$ & $* * *$ & $* *$ \\
\hline $\mathrm{Y} \times \mathrm{PD}$ & 1 & $* *$ & $*$ & NS & $* * *$ & $*$ & $*$ & NS & $* * *$ & $*$ & NS & NS \\
\hline $\mathrm{Y} \times \mathrm{C}$ & 6 & $*$ & $* *$ & $*$ & $* * *$ & $*$ & $*$ & $*$ & $* * *$ & $*$ & $* * *$ & NS \\
\hline $\mathrm{PD} \times \mathrm{C}$ & 6 & NS & NS & NS & $*$ & NS & NS & NS & $*$ & NS & $* * *$ & NS \\
\hline
\end{tabular}
June of 1999 and 2000 at the OARDC Vegetable Crops Research Branch in Fremont.

Ns, *,**,*** Nonsignificant or significant at $P=0.05,0.01$, or 0.001 , respectively. 
Table 2. Influence of year and planting date on yield and head traits of seven cultivars of fresh market cabbage planted at the OARDC Vegetable Crops Research Branch in Fremont, Ohio.

\begin{tabular}{|c|c|c|c|c|c|c|c|c|c|c|c|c|}
\hline \multirow[b]{3}{*}{ Main effect } & \multirow[b]{3}{*}{$\mathrm{N}$} & \multirow{3}{*}{$\begin{array}{c}\text { Marketable } \\
\text { yield } \\
\left(\mathrm{Mg} \cdot \mathrm{ha}^{-1}\right)\end{array}$} & \multicolumn{7}{|c|}{ Trimmed head } & \multicolumn{3}{|c|}{ Core } \\
\hline & & & \multirow{2}{*}{$\begin{array}{l}\mathrm{Wt} \\
(\mathrm{g})\end{array}$} & \multirow{2}{*}{$\begin{array}{l}\mathrm{Vol} \\
\left(\mathrm{cm}^{3}\right)\end{array}$} & \multirow{2}{*}{$\begin{array}{l}\text { Density } \\
\left(\mathrm{g} \cdot \mathrm{cm}^{-3}\right)\end{array}$} & \multicolumn{4}{|c|}{ Diameter $(\mathrm{cm})$} & \multirow{2}{*}{$\begin{array}{l}\text { Length } \\
(\mathrm{cm})\end{array}$} & \multirow{2}{*}{$\begin{array}{c}\text { Base } \\
\text { width }(\mathrm{cm})\end{array}$} & \multirow{2}{*}{$\begin{array}{c}\% \text { Head } \\
\text { vol }\end{array}$} \\
\hline & & & & & & Polar (P) & Equatorial (E) & Avg & $\mathrm{P} / \mathrm{E}$ & & & \\
\hline \multicolumn{13}{|l|}{ Year } \\
\hline 1999 & 70 & $63.4 \mathrm{~b}^{2}$ & $1285 \mathrm{~b}$ & $1531 \mathrm{~b}$ & $0.863 \mathrm{~b}$ & $14.02 \mathrm{~b}$ & $13.44 \mathrm{~b}$ & $13.73 \mathrm{~b}$ & $1.05 \mathrm{a}$ & $6.75 b$ & $3.02 \mathrm{~b}$ & $1.18 \mathrm{a}$ \\
\hline 2000 & 45 & $71.4 \mathrm{a}$ & $1847 \mathrm{a}$ & $1978 \mathrm{a}$ & $0.933 \mathrm{a}$ & $15.41 \mathrm{a}$ & $16.40 \mathrm{a}$ & $15.90 \mathrm{a}$ & $0.95 \mathrm{~b}$ & $8.16 \mathrm{a}$ & $3.12 \mathrm{a}$ & $1.11 \mathrm{a}$ \\
\hline $\operatorname{LSD}_{(0.05)}$ & & 7.3 & 130 & 145 & 0.030 & 0.42 & 0.51 & 0.45 & 0.02 & 0.30 & 0.09 & 0.12 \\
\hline \multicolumn{13}{|l|}{ Planting date } \\
\hline May & 55 & $76.7 \mathrm{a}$ & $1673 \mathrm{a}$ & $1903 \mathrm{a}$ & $0.882 \mathrm{a}$ & $15.17 \mathrm{a}$ & $14.89 \mathrm{a}$ & $15.03 \mathrm{a}$ & $1.04 \mathrm{a}$ & $7.43 \mathrm{a}$ & $3.17 \mathrm{a}$ & $1.14 \mathrm{a}$ \\
\hline June & 60 & $57.2 \mathrm{~b}$ & $1343 \mathrm{~b}$ & $1517 b$ & $0.898 \mathrm{a}$ & $13.98 \mathrm{~b}$ & $14.30 \mathrm{~b}$ & $14.14 \mathrm{~b}$ & $0.99 \mathrm{~b}$ & $7.17 \mathrm{a}$ & $2.95 \mathrm{~b}$ & $1.17 \mathrm{a}$ \\
\hline $\mathrm{LSD}_{(0.05)}$ & & 7.1 & 127 & 141 & 0.029 & 0.41 & 0.49 & 0.44 & 0.02 & 0.29 & 0.08 & 0.12 \\
\hline
\end{tabular}

${ }^{2}$ Numbers in the same column and main effect followed by the same letter are not significantly different according to Fisher's least significant difference test ( $\alpha$ $=0.05$ ).

Table 3. Influence of planting date on head traits of seven cultivars of fresh market cabbage planted in May and June of 1999 and 2000 at the OARDC Vegetable Crops Research Branch in Fremont, Ohio. Asterisks indicate that planting date had a significant effect on the variable listed within the cultivar according to analysis of variance $(P=0.05)$.

\begin{tabular}{|c|c|c|c|c|c|c|c|c|c|c|c|c|c|}
\hline \multirow[b]{3}{*}{ Cultivar } & \multirow{3}{*}{$\begin{array}{l}\text { Planting } \\
\text { date }\end{array}$} & \multirow[b]{3}{*}{$\mathrm{N}$} & \multicolumn{7}{|c|}{ Trimmed head } & \multicolumn{3}{|c|}{ Core } & \multirow{3}{*}{$\begin{array}{l}\text { No. of } 10 \text { trait } \\
\text { affected by } \\
\text { planting date }\end{array}$} \\
\hline & & & \multirow{2}{*}{$\begin{array}{l}\mathrm{Wt} \\
(\mathrm{g})\end{array}$} & \multirow{2}{*}{$\begin{array}{c}\text { Vol } \\
\left(\mathrm{cm}^{-3}\right)\end{array}$} & \multirow{2}{*}{$\begin{array}{l}\text { Density } \\
\left(\mathrm{g} \cdot \mathrm{cm}^{-3}\right)\end{array}$} & \multicolumn{4}{|c|}{ Diameter $(\mathrm{cm})$} & \multirow{2}{*}{$\begin{array}{l}\text { Length } \\
(\mathrm{cm})\end{array}$} & \multirow{2}{*}{$\begin{array}{c}\text { Base } \\
\text { width }(\mathrm{cm})\end{array}$} & \multirow{2}{*}{$\begin{array}{c}\% \text { Head } \\
\text { vol }\end{array}$} & \\
\hline & & & & & & Polar (P) & Equatorial (E) & Avg & $\mathrm{P} / \mathrm{E}$ & & & & \\
\hline \multirow{4}{*}{ Blue Dynasty } & & & $* *$ & & & & & & $* *$ & & & & 2 \\
\hline & May & 8 & 1611 & 1803 & 0.921 & 14.9 & 14.8 & 14.9 & 1.02 & 7.00 & 2.9 & 0.90 & \\
\hline & June & 8 & 1319 & 1526 & 0.861 & 14.11 & 4.6 & 14.3 & 0.98 & 6.98 & 2.9 & 0.98 & \\
\hline & $\operatorname{LSD}_{(0.05)}$ & & 272 & 326 & 0.064 & 0.9 & 0.96 & 0.90 & 0.04 & 0.624 & 0.18 & 0.148 & \\
\hline \multirow[t]{4}{*}{ Bronco } & & & & $* *$ & & $* *$ & & & $* *$ & & $* *$ & & 4 \\
\hline & May & 8 & 1978 & 2274 & 0.909 & 16.2 & 15.3 & 15.7 & 1.08 & 7.02 & 3.79 & 1.19 & \\
\hline & June & 8 & 1591 & 1757 & 0.880 & 14.8 & 14.9 & 14.8 & 1.00 & 6.92 & 3.27 & 1.16 & \\
\hline & $\operatorname{LSD}_{(0.05)}$ & & 442 & 505 & 0.052 & 1.36 & 1.51 & 1.4 & 0.04 & 0.92 & 0.31 & 0.10 & \\
\hline \multirow[t]{4}{*}{ Cheers } & & & $* *$ & $* *$ & & $* *$ & $* *$ & $* *$ & & & $* *$ & & 6 \\
\hline & May & 8 & 2027 & 2076 & 0.963 & 15.6 & 16.8 & 16.2 & 0.94 & 7.89 & 3.18 & 1.07 & \\
\hline & June & 9 & 1408 & 1415 & 0.999 & 13.7 & 14.9 & 14.3 & 0.94 & 7.05 & 2.84 & 1.12 & \\
\hline & $\operatorname{LSD}_{(0.05)}$ & & 449 & 509 & 0.109 & 1.32 & 1.61 & 1.42 & 0.05 & 0.96 & 0.14 & 0.16 & \\
\hline \multirow[t]{4}{*}{ DPSX 315} & & & $* *$ & $* *$ & & $* *$ & & $* *$ & $* *$ & & $* *$ & & 6 \\
\hline & May & 8 & 1511 & 1585 & 0.979 & 14.2 & 14.2 & 14.2 & 1.00 & 7.32 & 3.20 & 1.34 & \\
\hline & June & 8 & 1015 & 1029 & 1.009 & 12.2 & 12.8 & 12.5 & 0.96 & 6.77 & 2.82 & 1.52 & \\
\hline & $\operatorname{LSD}_{(0.05)}$ & & 336 & 362 & 0.064 & 1.38 & 1.64 & 1.50 & 0.03 & 0.83 & 0.29 & 0.26 & \\
\hline \multirow[t]{4}{*}{ Emblem } & & & & & $* *$ & & & & $* *$ & & & & 2 \\
\hline & May & 8 & 1459 & 1748 & 0.832 & 14.7 & 14.3 & 14.5 & 1.04 & 8.16 & 2.94 & 1.13 & \\
\hline & June & 8 & 1267 & 1651 & 0.765 & 14.3 & 14.4 & 14.4 & 1.00 & 7.55 & 3.08 & 1.19 & \\
\hline & $\operatorname{LSD}_{(0.05)}$ & & 314 & 324 & 0.057 & 1.06 & 1.29 & 1.15 & 0.04 & 1.01 & 0.25 & 0.12 & \\
\hline \multirow[t]{4}{*}{ Red Dynasty } & & & & $* *$ & $* *$ & $* *$ & & & $* *$ & & & & 4 \\
\hline & May & 7 & 1145 & 1841 & 0.624 & 15.1 & 12.9 & 14.0 & 1.18 & 6.91 & 3.06 & 1.29 & \\
\hline & June & 8 & 980 & 1361 & 0.731 & 13.5 & 12.5 & 13.0 & 1.08 & 6.88 & 2.89 & 1.19 & \\
\hline & $\operatorname{LSD}_{(0.05)}$ & & 249 & 317 & 0.054 & 1.05 & 1.17 & 1.10 & 0.03 & 0.53 & 0.18 & 0.81 & \\
\hline \multicolumn{3}{|c|}{ SuperElite Hybrid } & & & & & & & & & $* *$ & & 1 \\
\hline & May & 8 & 2026 & 2011 & 0.991 & 15.5 & 16.1 & 15.8 & 0.97 & 7.82 & 3.15 & 1.024 & \\
\hline & June & 8 & 1780 & 1862 & 0.996 & 15.1 & 15.9 & 15.5 & 0.96 & 8.09 & 2.94 & 1.019 & \\
\hline & $\operatorname{LSD}_{(0.05)}$ & & 428 & 345 & 0.109 & 1.02 & 1.64 & 1.28 & 0.06 & 0.849 & 0.21 & 0.109 & \\
\hline \multicolumn{3}{|c|}{$\begin{array}{l}\text { No. of } 7 \text { cultivars } \\
\text { affected by planting date }\end{array}$} & 3 & 4 & 2 & 4 & 1 & 2 & 5 & 0 & 4 & 0 & \\
\hline
\end{tabular}

were influenced by planting date in four to five of the seven cultivars studied (Table 3 ). However, head density and equatorial and average diameter were influenced by planting date in one to two of the cultivars studied. In addition, core length and core volume as percentage of head volume were influenced by planting date in none of the cultivars studied (Table 3). Likewise, planting date influenced six of the 10 head and core traits examined in two of the seven cultivars studied, 'Cheers' and 'DPSX315' (Table 3). But, four or less of 10 head and core traits were influenced by planting date in the remaining five cultivars studied (Table 3 ).

Planting date influenced the mean value of many head and core traits (Tables 2 and 3 ) and the distribution of values of individual heads (Fig. 1). Head p/e values from the June plant- ing tended to be more consistent and closer to 1.0 than $\mathrm{p} / \mathrm{e}$ values from the May planting (Fig. 1A). For example, $90 \%$ of the p/e values for the June planting were in the range 0.88 to 1.092 (avg. $=0.99$ ) whereas $90 \%$ of the $\mathrm{p} / \mathrm{e}$ values for the May planting were in the range 0.88 to 1.218 (avg. $=1.04$ ) (Fig. 1A). Trimmed head weight and volume values from the June planting were also distributed over more narrow and different ranges than in the May planting (Fig. 1B). Ninety percent of the trimmed head weight values ranged between 900 and $2617 \mathrm{~g}$, and 600 and $2117 \mathrm{~g}$ in the May and June planting, respectively (Fig. 1B, left). Also, $90 \%$ of the trimmed head volume values ranged between 1050 and $2900 \mathrm{~cm}^{3}$, and 750 and $2400 \mathrm{~cm}^{3}$ in the May and June planting, respectively (Fig. 1B, right).

Relationships among head and core traits.
Head diameter and weight were strongly related in the 550 heads examined in this study (Fig. 2A). Relationships between weight and average diameter for trimmed heads taken from May and June-planted plots were described by quadratic equations having $R^{2}$ values of 0.93 and 0.91 , respectively (Fig. 2A). Head volume and core volume were also related as cores occupied $\approx 1.13 \%$ of calculated head volume, on average (Fig. 2B). However, actual values for percent head volume in the core declined slightly with increasing head volume from a high of $1.42 \% \pm 0.41 \%$ at $0-1000 \mathrm{~cm}^{3}$ head volume $(\mathrm{N}=77)$ to $0.93 \% \pm 0.19 \%$ at head volumes $>3000 \mathrm{~cm}^{3}(\mathrm{~N}=29)$. In contrast, density was largely unrelated to the average diameter of trimmed heads over the range of diameter recorded in this study (Fig. 2C). Head diameter ranged from 7.40 to $21.05 \mathrm{~cm}$ (avg. 

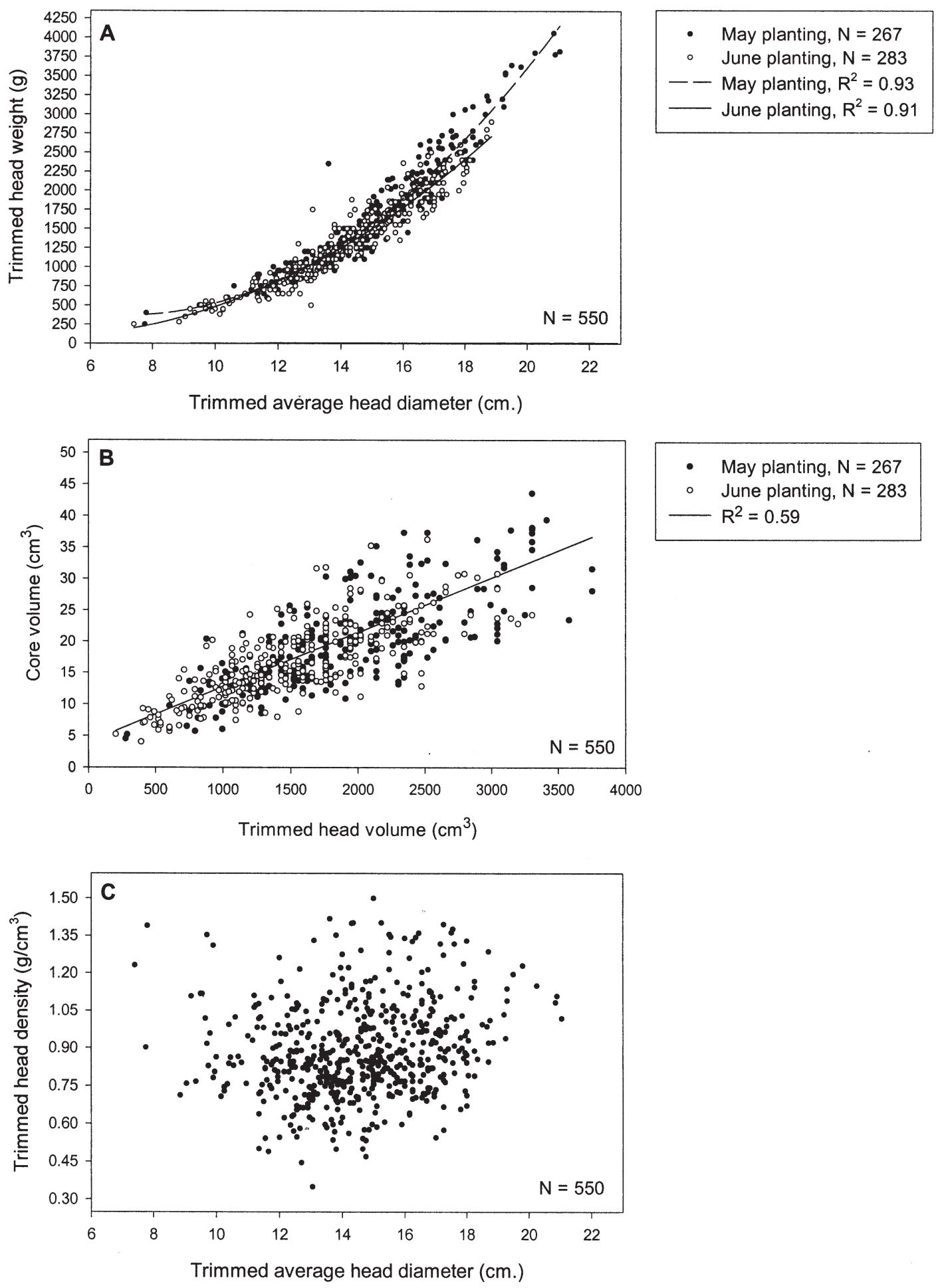

Fig. 2. Relationships between selected head and core traits in seven cultivars of fresh market cabbage after May and June planting in 1999 and 2000 at the OARDC Vegetable Crops Research Branch in Fremont, Ohio. (A) Head weight-average head diameter. (B) Head volume-core volume. (C) Head density-average head diameter. Head density was calculated using estimated head volume and direct measure of individual head weight. Average head diameter values are the mean of the polar and equatorial diameters for each head.

$=14.56 \mathrm{~cm}$ ) and head density from 0.349 to $1.500 \mathrm{~g} \cdot \mathrm{cm}^{-3}$ (avg. $\left.=0.889 \mathrm{~g} \cdot \mathrm{cm}^{-3}\right)$ with relatively minor effects of planting date on head density (data not shown).

\section{Discussion}

Cabbage head and core traits were influenced by year, cultivar, planting date. and, frequently, their interactions. Planting date has been shown to influence head and core traits under conditions different from this experiment (de Moel and Everaarts, 1990; Orzolek et al., 2000; Sundstrom and Story, 1984). For example, de Moel and Everaarts (1990) found smaller, lighter heads and lower marketable yield in June- and July-planted crops vs. May-planted crops but increases in core length with later planting on a marine loam soil in the Netherlands. Orzolek et al. (2000) reported that average marketable yield and head weight were greater in cabbage planted in July vs. April in Pennsylvania. And, they concluded that cultivars should be chosen based on the intended season (early/spring, late/summer) of planting. Sundstrom and Story (1984) also found that cultivar and growing season influ- 


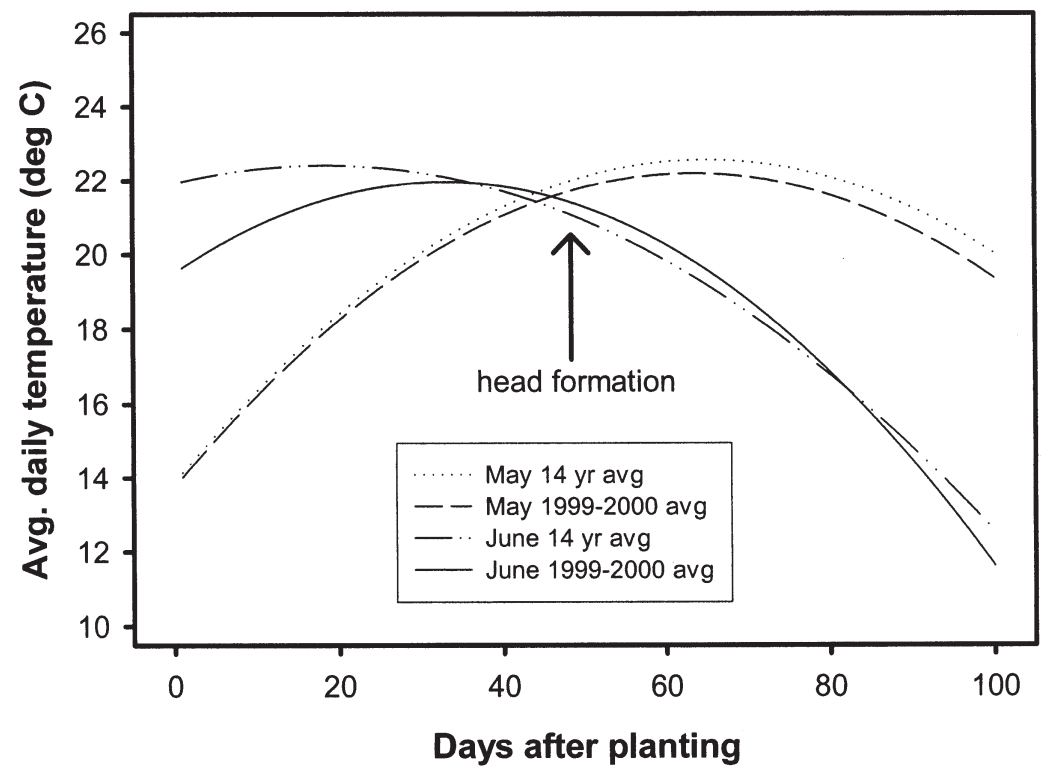

Fig. 3. Lines fit to polynomial equations for average daily temperature $\left({ }^{\circ} \mathrm{C}\right)$ values for May and June cabbage plantings near Fremont, Ohio. Lines for 14-year average based on 11 May and 18 June plantings.

enced head development in Louisiana. They also suggested that temperature had a significant effect on cabbage head shape as average head length/width ratios were greater in fall (August)- vs. spring (January)-planted crops. For the current experiment, a plot of typical seasonal temperature values for the study site helps explain why planting date influenced head and core traits. Figure 3 illustrates that average daily temperatures during main periods of crop development (i.e., pre-heading, heading) differed markedly for May- and June-planted crops. While average temperatures nearly peaked during head formation in May-planted crops, June-planted crops experienced higher temperatures before heading and lower temperatures during head formation (Fig. 3). Temperature, growing degree-day accumulation, and solar radiation are thought to influence cabbage head and core traits (Isenberg et al., 1975; Nilsson, 1988; Strandberg, 1979). Yet, the influence of abiotic growth factors on crop maturity, quantitative and qualitative changes in head and core carbohydrates, and head size, weight, moisture content, and density appears to vary with genetics (Howe and Waters, 1994; Isenberg et al., 1975; Nilsson, 1988; Orzolek et al., 2000; Strandberg, 1979; Strandberg and White, 1979). The large range in the number of traits affected by planting date both across and within the seven cultivars studied here is consistent with the premise that specific traits and individual cultivars are differentially influenced by environmental conditions (Table 3).

Nilsson (1988) reported that head and core carbohydrate levels responded differently to solar radiation, temperature, and degree-days. Also, hexose, sucrose, and total sugar levels correlated more strongly with degree-days over the whole growing cycle than with conditions within 2 weeks of harvest at crop maturity (Nilsson, 1988). This would suggest that specific head and core traits are a result of cumulative environmental conditions and that conditions early in plant and crop development may have a stronger influence on these traits than previously considered.

In this study, May planting tended to result in larger, heavier, and slightly different-shaped heads with cores having a larger base width than June planting (Table 2). In summary, data reported here are generally consistent with earlier findings that quantitative levels of cabbage head and core traits may be unique to specific genotype-environment combinations. If true, this would provide firm rationale for local evaluations of cultivar performance and, perhaps, screening of experimental selections under a wide range of contrasting environments.

In a 12-year study of yield of numerous genotypes of cabbage grown in Florida, Strandberg and White (1979) stated that well-accepted cultivars exhibited less variation in yield and head weight. Unfortunately, identifying cultivars or experimental selections with consistently positive traits (across a range of environments) is increasingly difficult. Large-scale evaluations are increasingly resource-demanding as the need for more sophisticated market quality-oriented data increases. Therefore, an objective of this study was to examine relationships among key head and core traits. Documenting relationships among important traits under a range of genotype $x$ environment combinations may help lead to more efficient large-scale cultivar evaluations and further explain the influence of genetic and environmental factors on key traits.

In considering the relationships between head traits reported here, it is important to note that individual plots were harvested once and that specific relationships for individual heads may change during development and maturation. Nevertheless, polar (longitudinal) and equatorial (medial) diameter values were often similar (Fig. 1A), that is, head p/e values were often close to 1.0 (Fig. 1A). Overall, 50\% of $\mathrm{p} / \mathrm{e}$ values were in the range 0.93 to 1.08 with a mean value of 1.01 (Fig. 1A). Similar ranges of head length : width values have been reported for different genotype $\times$ environment combinations (de Moel and Everaarts, 1990; Fornaris-Roullan et al., 1989; Orzolek et al., 2000; Sundstrom and Story, 1984). Therefore, although absolute head shape may vary with specific genotype $\times$ environment interactions (Table 1), the strong, overall trend is toward round heads. Therefore, reliable estimates of head volume may be used to calculate head density, which is a leading indicator of cabbage crop quality. Head weight-diameter and head volume-core volume relationships were also consistent (Fig. 2A, 2B) and contributed to the development of a tool for the preharvest estimation of cabbage crop yield (Kleinhenz, 2003).

In contrast to other head and core traits, head density and diameter were unrelated. Smaller, market-ready heads were as dense as larger heads and density varied considerably at specific head sizes (Fig. 2C). Anecdotal evidence suggests that larger heads are also more dense, but we found no evidence to support this view. Furthermore, the ratio of head fresh to dry weight, possibly a primary determinant of head density, is reported to remain nearly constant throughout development, with slight declines near maturity (Strandberg, 1979). Isenberg et al. (1975) also found a relatively weak relationship between head weight and density in heads at later stages of maturity. Together, data of Isenberg et al. (1975) and this study suggest that direct measures of density are required in large-scale cultivar development or evaluation projects. So long as trimmed heads are spherical, methods reported here permit rapid and reliable estimates of head density.

In conclusion, genetic and environmental effects on important head traits are best identified in studies involving a large number of cabbage genotypes grown in many contrasting environments (years, locations within years). Reports from such studies are rare and have been partly replaced with shorter-term studies, possibly involving fewer genotypes. In this respect, data reported here reinforce earlier results that head and core traits are influenced by genotype $x$ environment interactions. The data also provide valuable evidence that relationships between specific head and core traits are consistent. The stability of these relationships may have practical and scientific value. For example, predictable relationships between selected cabbage head and core traits could help increase the efficiency of large-scale germplasm evaluations. Strandberg and White (1979) concluded that local "variety trials" provide key information in the selection of locally adapted cultivars and appropriate harvest dates. Unfortunately, largescale, comprehensive cabbage germplasm evaluations useful to contemporary growers, markets, and industries are increasingly difficult to complete. This presents the investigator and industry partners with challenges that may be partially overcome by increasing the efficiency of evaluations. Greater efficiency could be derived from inclusion of only those factors known to influence important crop and head variables on a local scale. In addition, 
reducing the number of variables measured based on documented relationships among key traits could reduce the resources needed to complete evaluations with minimal sacrifices in the information gained.

\section{Literature Cited}

de Moel, C.P. and A.P. Everaarts. 1990. Growth, development, and yield of white cabbage in relation to time of planting. Acta Hort. 267: 279-288.

Fornaris-Rullan, G., I. Beauchamp de Caloni, and L. Avilez-Rodriguez. 1989. Head characteristics and acceptability of cabbage cultivars grown in southern Puerto Rico. J. Agr. Univ.,
P.R. 73:367-373.

Greenland, R.G., C.W. Lee, E.T. Holm, and L.E. Besemann. 2000. Cabbage hybrid trials in North Dakota. HortTechnology 10:806-811.

Howe, T.K. and W.E. Waters. 1994. Two-year summary of cabbage cultivar yield trials. Proc. Fla. State Hort. Soc. 107:95-99.

Isenberg, F.M.R., A. Pendergrass, J.E. Carroll, L. Howell, and E.B. Oyer. 1975. The use of weight, density, heat units, and solar radiation to predict the maturity of cabbage for storage. J.Amer. Soc. Hort. Sci. 100:313-316.

Kleinhenz, M.D. 2003. A proposed tool for pre-harvest estimation of cabbage yield. HortTechnology 13:182-185.

Nilsson, T. 1988. Growth and carbohydrate composition of winter white cabbage intended for long-term storage. II. Effects of solar radiation, temperature, and degree-days. J. Hort. Sci. 63: 431-441.

Orzolek, M.D., W.J. Lamont, and L. Otjen. 2000. 1997 Spring and fall cabbage cultivar trials in Pennsylvania. HortTechnology 10:218-221.

Strandberg, J.O. 1979. Growth and phenology of cabbage in a winter production area. Proc. Fla. State Hort. Soc. 92:93-96.

Strandberg, J.O. and J.M. White. 1979. Estimating fresh market cabbage maturity dates in a winter production area. Proc. Fla. State Hort. Soc. 92:96-99.

Sundstrom, F.J. and R.N. Story. 1984. Cultivar and growing season effects on cabbage head development and weight loss during storage. HortScience 19:589-590. 